\title{
TULEVAISUUS EILEN, TÄNÄÄN JA HUOMENNA
}

Future of library, I,2 miljoonaa osumaa Googlessa. Future of academic library, 88 ooo osumaa. Kirjaston tulevaisuus tai tulevaisuuden kirjasto, yhteensä 4000 osumaa.

Tulevaisuus kiinnostaa kirjastoihmisiä. Future Library -nimellä kulkee useampikin hanke, teos ja tapahtuma, ja ainakin yksi taideteos: Future Library project on vuonna 20 I 4 alkanut taideprojekti, jossa kirjasto avautuu vuonna 2 I I4. Sitä ennen kokoelma kasvaa vuosittain yhdellä uudella ennen julkaisemattomalla teoksella. Mukana on jo Karl Ove Knausgaardin, Margaret Atwoodin ja Elif Shafakin kaltaisia kirjailijoita. He ovat kirjoittaneet jotain, joka on luettavissa heti ensi vuosisadalla.

Kirjastoalalla tulevaisuuden pohdiskelu ja analysointi saa usein vauhtia teknologian kehitykseen liittyvistä odotuksista, teknologista determinismiäkään kaihtamatta. Tulevaisuusskenaarioita on laadittu aina, mutta varsinkin internetin kehitys ja digitalisaatio ovat olleet luontevaa maaperää visioinnille. Tiedon järjestäminen ja tietoaineistojen saatavuuden takaaminen ovat kirjaston perinteisiä ydintoimintoja, ja nämä ovat olleet suuren murroksen kohteena viime vuosikymmeninä.

Kirjastovisioinnin taustalla voi olla tiedonjanoa, politiikkaa, käytännön strategiatyötä, ammatillista itseruoskintaa ja milloin mitäkin. Halu olla relevantti ajasta ja muutoksesta toiseen lienee silti tärkeimpiä motiiveja - kirjasto haluaa kehittyä maailman mukana. Tämä tarkoittaa, että kirjaston tulevaisuus kytketään sen käyttäjien moninaisten tarpeiden muuttumiseen, teknologian kehitykseen ja yhteiskunnalliseen kehitykseen.

Nyt uuden vuosikymmenen kynnyksellä kirjasto on yhä relevantti. Ja tästä halutaan pitää kiinni, joten tulevaisuutta pohditaan, tässäkin lehdessä.

Kaukokatseinen visiointi voi tuntua liioittelulta aikana, jolloin maailma on pysähtynyt paikoilleen. Tieteellisissä kirjastoissa korona-aikaan siirryttiin käytännössä alle viikossa maaliskuussa. Siinä ajassa ei ehdi juuri tulevaisuuteen varautua, vaan pikemminkin tulee näkyviin se työ, mitä on tehty - visioitu, suunniteltu ja toteutettu.

"Kukaan ei olisi osannut syksyllä arvata, kun kirjasto käynnisti etäohjauksen pilotin yhdessä yliopiston opiskelijapalveluiden kanssa, kuinka keskeisessä asemassa etäohjaus tulisi olemaan kevään poikkeusoloissa.” Vastaavia esimerkkejä on paljon. Monissa kirjastoissa on suunniteltu ja toteutettu verkon välityksellä tarjottavia palveluita, vaikka mielessä ei ole ehkä ollut virustautipandemia.

Paljon ehdittiin tehdä tai laittaa alulle myös sen maaliskuisen viikon aikana, kun poikkeustila astui voimaan: palveluiden uudelleenjärjestelyn suunnittelua ja toteutusta, viestintää eri muodoissa ja eri kanavissa erilaisille asiakasryhmille, aineistojen sähköisen

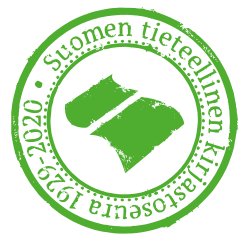


saatavuuden selvittämistä, tietojärjestelmäpuolen ongelmien ratkomista, etäopetuksen ja -ohjauksen suunnittelua, lähiopetusten muuttamista webinaareiksi, etätyöskentelyyn siirtymistä, etätyöskentelyn ja -opetuksen tuen organisointia, kokousten siirtämistä verkkoon, tapahtumien peruuttamista, kalenterin uudelleenjärjestelyä. Ja niin edelleen.

Hyvä esimerkki suunnitelmien äkkinäisestä muuttumisesta on tässäkin lehdessä esillä oleva Berliinin Open Science 2020 -konferenssi, joka keskeytettiin ensimmäisen päivän jälkeen. Kirjastoalan tapahtumista Liberin vuosittainen konferenssi Belgradissa ja IFLAn wLIC -kongressi peruttiin tai siirrettiin verkkoon hallitummassa järjestyksessä. Suomen tieteellisen kirjastoseuran (sTKS) sääntömääräinen kevätkokouskin jää tältä keväältä väliin, mutta se järjestetään syyskuun loppuun mennessä.

Mitä korona-ajasta voidaan oppia? Kirjastoissa kypsyvät omat innovaationsa, mutta asiaa voi tarkastella laajemminkin.

Itä-Suomen yliopiston kirjastonjohtaja ja sTKs:n entinen puheenjohtaja Jarmo Saarti avasi huhtikuussa Helsingin Sanomissa keskustelua kansallisesta tietohuoltovarmuudesta. Ajatus on yksinkertainen: tutkimuksen, opetuksen ja asiantuntijatyön tietolähteiden saatavuus on taattava myös kriisiaikana. Toteutus on monen strategisen, tulevaisuutta rakentavan siirron summa, jonka päätepisteenä siintelee open access jossain muodossa, tai monessa muodossa.

Tietohuoltoa turvattiin akuutisti jo kevään aikana, kun kustantajat osallistuivat koronatalkoisiin avaamalla maksumuurin takana olevia korona-aineistojaan. Hieman kaukokatseisempaa näkemystä tiedon saatavuuteen edustaa tekijänoikeutta ja lähioikeuksia sisämarkkinoilla käsittelevä DSM-direktiivi, jota sovitellaan parhaillaan kansalliseen lainsäädäntöön opetus- ja kulttuuriministeriössä.

DSM-direktiivissä määritellään tekstin- ja tiedonlouhinnan pelisäännöt. Kannanotossaan sTKs yhdessä Suomen yliopistokirjastojen verkoston (FUN) kanssa ottaa kantaa paitsi mahdollisimman vapaan tutkimuskäytön puolesta myös rinnakkaistallennuspoikkeuksen puolesta. Tämä on tietohuoltovarmuudesta - eli tiedon vapaasta saatavuudesta - huolehtimista arkisimmillaan. STKS:n ja FUNin kannanotto löytyy kokonaisuudessaan STKs:n verkkosivuilta.

Tulevaisuudesta vielä: ensi syksyn numeroiden suunnittelu on alkanut, mutta kirjoitusideoita mahtuu hyvin mukaan. Ottakaa yhteyttä! Edellisessä numerossa esitelty ajatus Signumin toimitusverkostosta on todellistunut mukavasti kevään aikana, ja ovi on auki kiinnostuneille myös jatkossa. 